\title{
ANALISIS DETERMINAN KESESUAIAN PENERAPAN PERATURAN KOMISI PEMILU RI NO. 5 TAHUN 2017 TENTANG DANA KAMPANYE PESERTA PEMILIHAN GUBERNUR DAN WAKIL GUBERNUR, BUPATI DAN WAKIL BUPATI, DAN/ATAU WALIKOTA DAN WAKIL WALIKOTA
}

\author{
Budi Rofelawaty \\ Budi63@gmail.com \\ Abdul Kadir \\ STIE Indonesia Kayutangi Banjarmasin
}

\begin{abstract}
In the implementarion of the simultaneously post election in 2018, the Election Commission of Republic Indonesian issued regulation No.5/2017 concerning compaign funds for the participants of the Governor an Deputy Governon, regent and Deputy Regent, and/or Mayor and deputy Mayor. This research is directed at the determinants of the compliance with the implementation of the Election Commission regulation, both by candidate pairs and by the political parties, whichs aims to find out what factors influence the implementaion of that KPU RI regulation.

The assessment process is carried out objectively, systematically, rationally, which is supported by empirical facts in order to find the truth, for the the purpose of developing science, especially regional finance, which is related to compaign funds. The research technique was carried out with descriptive fenomenology, with the location of the study being the election commission located in 11 districts and 2 municipalities in South Kalimantan province. The descriptive fenomenology approach was used by researcher to explore the phnomenon because the participants wanted to know about it (as many as 10 key person as related informants) and the researchers acted as instrumentes in teh ddata collection process.

The results of the study indicate that there are several things that have the potential to be determinants of the suitability of the implementation of The RI Election Commision regulation No.5/2017 are the electoral system and compaign finance management, the existence of a high-cost compaign process, the content of ele toral policies and the context of policy implementation (in relation of the level human resources competence, the availability of adewuate human resources, the power of actors in influencing the effectiveness for political elite)
\end{abstract}

Keywords: System of procurement, compaign funds, political elite, and the influence of the power of actor 


\section{PENDAHULUAN}

Sumber utama dana untuk kegiatan politik seperti kampanye umumnya berasal dari para partisipan partai. Ketika para kandidat mulai mengumumkan keikutsertaannya dalam kegiatan kampanye maka para kandidat akan meminta dukungan finansial, terutama dukungan dari partai politiknya dan dukungan dari partai politik akan sering dapat memberikan promosi pada akses organisasiorganisasi sekutu partai politik tersebut dengan peluang untuk mendapatkan pendanaan.

Penggalangan atau pengumpulan dana yang akan digunakan oleh para kandidat politik dalam pemenuhan atas biaya-biaya atau pengeluaran saat kampanye politik. Untuk itu para kandidat tersebut benar-benar mengusahakan untuk memulai penggalangan dana sesegera mungkin, bahkan jauh hari sebelumnya para kandidat tersebut mengumumkan keikutsertaannya dalam pemilu. Penggalangan dana awal diperlukan para kandidat untuk menyewa ruang, instalasi telpon, memesan persediaan dan pembelian ruang iklan, karena strategi dan kualitas dari kampanye tergantung pada dana yang tersedia pada partai politiknya. terlebih dengan sistem pemilu langsung yang diterapkan di Indonesia sekarang menjadikan sistem pemilu ini berbiaya tinggi.

Menurut UU Nomor 2 tahun 2011 partai politik adalah organissasi yang bersifat nasional dan dibentuk oleh sekelompok warga negara Indonesia secara sukarela atas dasar kesamaan kehendak dan cita-cita untuk memperjuangkan dan membela kepentingan politik anggota, masyarakat, bangsa dan negara, serta memelihara keutuhan Negara Kesatuan Republik Indonesia berdasarkan Pancasila dan Undang Undang Dasar Negara Republik Indonesia tahun 1945.

Sifat dasar partai politik adalah perolehan kekuasaan atas nama rakyat yang dilakukan melalui pemilu. Bila menang dalam Pemilu, partai politik akan memegang kekuasaan melalui jalur pengambil keputusan (eksekutif) dan jalur pembuat kebijakan (legislatif). Setiap keputusan yang dibuat oleh partai politik melalui kedua jalur tersebut dan selalu mengatas namakan rakyat, dan berdampak Jurnal Komunikasi Bisnis dan Manajemen

Vol.5 No.2 Juli 2018 
luas terhadap kehidupan rakyat. Oleh karena itu partai politik seharusnya memastikan bahwa setiap tindakannya dilakukan demi rakyat yang diwakilinya, bebas dari politik uang dan pengaruh kelompok kepentingan.

Namun kenyataannya, sulit sekali melepaskan partai politik dari pengaruh kelompok kepentingan karena kehidupan partai politik justru tergantung pada sumbangan yang diterimanya. Sehingga sangat mudah bagi kelompok kepentingan untuk memengaruhi partai politik melalui sumbangan yang diberikannya. Bila ini terjadi, orientasi partai politik bukan lagi kepada rakyat melainkan kepada kepentingan para donaturnya. Terlebih dengan sistem pemilu langsung menjadikan sistem pemilu yang berbiaya tinggi. Tingginya biaya politik untuk bertarung dalam pemilihan kepala daerah (pilkada) menjadi salah satu faktor paslon tidak melaksanakan peraturan yang tealh ditetapkan berkaitan dengan dana kampanye.

Negara-negara di dunia menggunakan berbagai jenis peraturan untuk meminimalisir dampak buruk yang dapat ditimbulkan oleh uang di dunia politik tanpa menghambat tumbuhnya demokrasi. Oleh karena itu pembatasan sumbangan kepada partai politik mutlak diperlukan. Selain itu laporan keuangan yang transparan dan bertanggungjawab dapat menghindari terjadinya politik uang karena setiap pemasukan dan pengeluaran keuangan akan tercatat dan diinformasikan dengan jelas. Akibatnya para pelaku politik tidak akan bisa mengalokasikan uang partai politik untuk tujuan-tujuan yang tidak bisa dipertanggungjawabkan atau yang melawan peraturan dan perundangan yang berlaku.

Dalam pelaksanaan pemilukada serentak tahun 2018 ini Komisi Pemilu mengeluarkan PP Komisi Pemilu RI NO. 5 tahun 2017 tentang dana kampanye peserta pemilihan Gubernur dan Wakil Gubernur, Bupati dan Wakil Bupati, dan/atau Walikota dan Wakil Walikota. Pada peraturan ini mengatur tentang dana kampanye yang digunakan oleh pasangan calon dan/atau partai poitik atau gabungan partai politik untuk membiayai metode kampanye yang dibiayai oleh pasangan calon yang bersangkutan sebagaimana dimaksud dalam peraturan KPU tentang kampanye pemilihan. 
Dalam penelitian ini peneliti memfokuskan pada hukum pemilu yaitu peraturan Komisi pemilu NO.5 tahun 2017 tentang Dana Kampanye peserta pemilihan Gubernur dan Wakil Gubernur, Bupati dan wakil Bupati, dan/atau Walikota dan Wakil Walikota. Analisis diarahkan pada determinan kesesuaian penerapan peraturan terseebut, baik oleh pasangan calon maupun oleh partai politik.

Sugiwa dkk (2015) menyebutkan bahwa pelaksanaan pemilu harus didukung oleh adanya transparansi keuangan partai-partai politik peserta pemilu untuk mengurangi berbagai bentuk kecurangan. Salah satunya adalah penyelewengan dana kampanye. Penelitian ini berkaitan dengan perilaku etis dan audit kepatuhan, dengan menganalisis determinan kesesuaian penerapan peraturan Komisi Pemilu RI No.5 tahun 2017 tentang dana kampanye untuk menciptakan pemilu yang fair, transparan dan akuntabel. Penelitian ini menganalisis tentang perilaku etis yang berkaitan dengan audit kepatuhan penerapan peraturan Komisi Pemilu tersebut dilakukan dalam tataran non positivistik yang tidak dapat diperoleh dengan menggunakan prosedur-prosedur statistik atau cara-cara lain dari kuantifikasi. Oleh karena itu dalam penelitian ini peneliti menggunakan metode kualitatif deskriptif fenomenologi untuk menemukan dan memahamai apa yang tersembunyi dibalik fenomena yang kadangkala merupakan sesuatu yang sulit untuk dipahami secara memuaskan.

\section{TINJAUAN PUSTAKA}

1. Pengertian partai politik

Menurut Budiardjo (2004) partai politik adalah suatu kelompok yang terorganisir yang anggotanya memunyai orietnas, nilai dan cita-cita yang sama dan tujuan yang sama, yaitu untuk memperoleh kekuasaan politik dan merebut kedudukan politik, dengan cara konstitusional guna melaksanakan kebijakankebijakan mereka. Pada Undang-Undang Nomor 2 tahun 2011 pasal 1 ayat (1) menyebutkan baha partai politik adalah organisasi yang berifat nasional dan dibentuk oleh sekelompok warga negara Indonesia secara sukrela atas dasar Jurnal Komunikasi Bisnis dan Manajemen

Vol.5 No.2 Juli 2018 
kesamaan kehendak dan cita-cita untuk memperjuangkan dan membela kepentingan poitik anggota, masyarakat, bangsa dan negara serta memelihara keutuhan negara Republik Indonesia berdasarkan Pancasila dan Undang- Undang Dasar Republik Indonesia tahun 1945. Berdasarkan beberapa pengertian tersebut menjelaskan bahwa partai politik mengemban tugas yang mulia dalam pemerintahan yang demokratis, karena segala kegiatan yang dijalankan oleh Partai Politik berorientasi pada kepentingan rakyat bukan pada golongan/elit tertentu.

\section{Perlunya Pengaturan akan Dana kampanye}

Sifat dasar partai politik adalah perolehan kekuasaan atas nama rakyat yang dilakukan melalui Pemilu. Setiap keputusan yang diambil oleh Partai Politik selalu mengatasnamakan rakyat, dan berdampak luas terhadap kehidupan rakyat. Oleh karena itu, partai politik seharusnya memastikan bahwa setiap tindakannya dilakukan demi rakyat yang diwakilinya, bebas dari politik uang dan pengaruh kelompok kepentingan. Namun kenyataannya, sulit sekali melepaskan partai politik dari pengaruh kelompok kepentingan, karena kehidupan partai politik tergantung pada sumbangan yang diterimanya. Sehingga sangat mudah bagi kelompok kepentingan untuk memengaruhi partai politik melalui sumnbangan yang diberikannya. Bila hal ini terjadi, orientasi partai politik bukan lagi kepada rakyat melainkan kepada kepentingan para donaturnya.

Oleh karena itu, pembatasan sumbangan kepada partai politik mutlak diperlukan. Selain itu, laporan keuangan yang transparan dan bertanggung jawab dapat menghindari terjadinya politik uang karena setiap pemasukan dan pengeluaran keuangan akan tercatat dan diinformasikan secara jelas. Akibatnya, para pelaku politik tidak akan bisa mengalokasikan uang partai politik untuk tujuan-tujuan yang tidak bisa dipertanggungjawabkan atau yang melawana peraturan dan perundangan yang berlaku.

Menurut Ohman \& Zainulbhai (2009) menyebutkan bahwa pemilu yang adil dan bebas, politik demokratis, pemerintahan yang efektif, dan korupsi, pendanaan partai politik dan kampanye pemilu seluruhnya terkait dengan keuangan politik. Jurnal Komunikasi Bisnis dan Manajemen

Vol.5 No.2 Juli 2018 
Kesemuanya itu secara positif dan negatif memengaruhi, dana yang cukup dapat memungkinkan peserta pemilu merangkul pemilih, namun terlalu banyak juga dapat mendistorsi kompetisi pemilu. Setelah pemilu selesai, sumber daya dibutuhkan untuk dialog efektif dengan masyarakat, namun pejabat publik mungkin memiliki tanggung jawab kepada para donatur yang besar, sehingga memengaruhi responsifnya terhadap kepentingan masyarakat dan efektivitas pengelolaan dana negara mereka.

Menurut Pinto-Duschinsky (2006) hal 69 menyatakan sangat jarang proses demokrasi melalui Pemilu tanpa skandal tentang keuangan politik di dunia ini. Skandal tersebut seringkali menandakan bahwa aturan keuangan politik tidak bekerja dengan semestinya. Frekuensi penerapan dan pembaruan UU kampanye atau pendanaan politik adalah bukti gagalnya sistem peraturan dan subsidi saat ini. Pembaruan atas UU atau peraturannya mungkin yang tidak cukup kuat, atau undang-undang atau peraturannya yang tidak diterapkan. Selain itu, keuangan politik sifatnya sedemikian rupa sehingga harus selalu ditinjau ualng dan diubah seiring dengan perkembangan konteks politik, ekonomi dan administratif.

Kemudian Walecki (2006) hal 19 menyatakan bahwa harus diakui bahwa skandal keuangan politik juga mengindikasikan bahwa ada kebebasan berekspresi bagi orang-orang yang menginvestigasi kasus dan mempublikasikan informasi kegiatan yang salah dan ada kesadaran masyarakat sehingga masyarakat tidak setuju kepada tindakan salah tersebut. Cakupan yang luas dari peran uang dalam politik mengakibatkan adanya kesulitan legislasi dan penegakan undang-undang terkaot trasnparansi dan kepatutan, sebab penyelesaian untuk satu hal dapat membuat celah untuk hal lain. Untuk itu harus ada peraturan dan penegakan yang lebih komprehensif.

Kemudian Ohman \& Zainulbhai (2009) hal 16-21 menyebutkan tentang pemahaman kunci global terkait dengan keuangan politik adalah:

a. Uang diperlukan untuk politik demokratis, dan partai politik harus memiliki akses ke dana untuk memainkan peran mereka dalam proses politik. Peraturan tidak harus mengekang persaingan yang sehat 
b. Uang tidak pernah menjadi bagian bermasalah dari istem politik, dan dibutuhkan regulasi

c. Konteks dan budaya politik harus diperhitungkan ketika merancang strategi untuk mengendalikan uang dalam politik

d. Regulasi dan pengungkapan efektif dapat membantu mengontrol efek samping uang dalam politik, tetapi hanya jika dipahami dan dilaksanakan dengna baik

e. Pengawasan efektif tergantung pada kegiatan dan interaksi dengan cara pemangku kepentingan (seperti regulator, masyarakat sipil dan media) dan harus didasarkan pada transparansi.

3. Peraturan Komisi pemilu RI No. 5 tahun 2017

Peraturan Komisi Pemilu RI No. 5 Tahun 2017 adalah tentang dana kampanye peserta pemilihan Gubernur dan wakil Gubernur, Bupati dan wakil Bupati, dan/atau walikota dan wakil walikota. Ruang lingkup peraturan KPU ini merupakan dana kampanye yang digunakan oleh Pasangan Calon dan atau partai politik atau gabungan partaia politik untuk membiayai metode kampanyeyang dibiayai oleh pasangan calon yang bersanagkutan sebagaimana dimaksud dalam peraturan KPU tentang kampanye pemilihan.

Tujuan pengaturan KPU ini yaitu:

a. Memberikan panduan bagi pasangan calon dalam mengelola dan mempertanggungjawabkan penerimaan dan pengeluaran dana kampanye, dan

b. Menjadi acuan bagi AP dalam melaksanakan audit kepatuhan atas laporan penerimaan dan pengeluaran dana kampanye

Kemudian sumber, bnetuk dan pembatasan pembiayaan dana kampanye diatur dalam bagian satu pasal 4 menyebutkan

a. Dana kampanye pasangan calon dari partai politik atau gabungan partai politik bersumber dari:

- Pasangan calon

- Partai politik atau gabungan partai politik pengusul, dan/atau

- Sumbangan yang sah menurut hukum dari pihak lain

b. Dana kampanye pasangan calon perseorangan berumber dari:

Jurnal Komunikasi Bisnis dan Manajemen

Vol.5 No.2 Juli 2018 
- Pasangan calon, dan/atau

- Sumbangan yang sah menurut hyukum dari pihak lain

\section{METODE PENELITIAN}

Penelitian ini menggunakan metode kualitatif deskriptif fenomenologi yang merupakan suatu metode penelitian yang kritis dan menggali fenomena yang ada secara sistematis, dengan menekankan pada subjektivitas pengalaman hidup manusia, dan metode ini merupakan penggalian langsung pengalaman yang disadari dan menggambarkan fenomena yang ada tanpa terpengaruh oleh teori sebelumnya yanga mungkin tidak perlu menguji dugaan atau anggapana sebelumnya. Anaisis yang lebih mendalam dalam peenlitian ini adalah menggali semua fenomena yang terjadi di masyarakat khususnya masyarakat politik sehingga diharapkan dapat menemukan fakta-fakta yang berkaitan permasalahan penelitian, dan tercapainya tujuan penelitian yaitu Untuk mengetahui apakah ada kendala bagi pasangan calon dalam menerapkan peraturan dimaksud dalam rangka penegakan transparansi dan akuntabilitas sesuai dengan yang diamanahkan oleh peraturan KPU RI no. 5 tahun 2017 tersebut.

\section{Desain penelitian}

Proses pengkajian dilakukan secara objektif melalui wawancara langsung dengan key person (informasi kunci), yang dilakukan secara sistematik, rasional, yang didukung dengan fakta empiris dalam rangka mencari kebenaran, untuk tujuan mengembangkan ilmu pengetahuan khususnya ilmu sosial politik. Alasan peneliti menggunakan metode kualitatif dalam penelitian ini adalah karena penelitian ini juga bertujuan untuk mengkaji makna yang tersembunyi dari fenomena riil yang ada di masyarakat. Untuk mencapai tujuan itu semua maka teknik penelitian yang dilakukan peneliti adalah dengan cara fenomonologi deskriptif dan etnometodologi. Penelitian dilakukan dengan pendekatan fenomonologi deskriptif bertujuan untuk mendapatkan penjelasan tentang realitas sosial yang tampak sehingga peneliti dapat memaknai tentang proses berpolitik yang ada dalam proses PEMILUKADA yang ada di Provinsi Kalimantan Selatan Jurnal Komunikasi Bisnis dan Manajemen

Vol.5 No.2 Juli 2018 
merupakan fenomena sosial politik yang ada di wilayah yang menjadi objek penelitian. Kemudian pendekatan etnometodologi digunakan dalam upaya mendeskripsikan dan memahami faktor sosial politik masyarakat yang ada berdasarkan kehidupan berpolitik sehari-harinya. Proses penelitian yang dilakukan dengan cara melakukan interaksi pelaku sosial politik yang ada di wilayah yang menjadi objek penelitian.

2. Lokasi penelitian

Lokasi penelitian adalah KPUD yang berada di 13 kabupaten/kota yang berada di Provinsi Kalimantan Selatan, dan akan melakukan pemilukada pada tahun 2018 ini. Peneliti menggunakan 16b (enam belas) informan atau key person yang kami anggap dapat memberikan informasi yang dibutuhkan untuk kelancaran perolehan data penelitian ini. Ke sepuluh informam ini kami samarkan namanya, dan persional yang akan menjadi informan dalam penelitian ini dapat dilihat pada tabel berikut:

Tabel 1.1. Daftar Informan dan posisi jabatannya

\begin{tabular}{|c|l|l|}
\hline No & \multicolumn{1}{|c|}{ Nama (Samaran) } & \multicolumn{1}{|c|}{ Jabatan } \\
\hline 1 & Bapak Saberan & Ketua DPW Partai \\
\hline 2 & Bapak Fadli & Kepala Bawaslu \\
\hline 3 & Bapak Norman & Anggota DPRD \\
\hline 4 & Bapak Syukriansyah & Bendahara DPW Partai \\
\hline 5 & Bapak Edy Gunawan & Pimpinan PT. Daerah sbg donartor Partai \\
\hline 6 & lbu Asmah & Staf Keuangan Partai \\
\hline 7 & Bapak Zainuddin \& & Pasangan Calon Bupati dan Wakil Bupati \\
\hline 8 & Wisnu & Auditor Laporan Keuangan Partai \\
\hline 9 & Bapak Yasin & Konultan Keuangan \\
\hline 10 & Bapak Nainggolan & Konsultan Hukum \\
\hline
\end{tabular}

\section{HASIL DAN PEMBAHASAN}

Baru tahun 1999, sistem hukum dan perundang-undangan pemilu di Indonesia mulai mengatur tentang dana kampanye (UU nomor tahun 1999 pasal 48 yang mengatur tentang dana kampanye pemilu). Meskipun banyak kalangan yang meragukan akan efektivitas aplikasi peraturan ini yang bertujuan untuk mendorong Jurnal Komunikasi Bisnis dan Manajemen

Vol.5 No.2 Juli 2018 
terbangunnya sistem kompetisi yang sehat dalam pemilu tersebut. Pada Pemilu tahun 2009 KPU Kabupaten/kota pada 36 Provinsi yang ada di Indonesia, bersepakat akan menjatuhkan sanksi kepada partai politik yang dinyatakan melanggar ketentuan tentang laporan dana kampanye. Sebagai bukti penerapan peraturan tersebut KPU telah mebatalkan/menggugurkan calon anggota DPRD di 6 Provinsi.

Hal ini menandakan bahwa ada perkembangan yang signifikan dalam proses penegakan hukum terkait dengan pengaturan tentang dana kampanye dalam pemilu, dan dapat memberi gambaran tentang bagaimana pengaturan dana kampanye telah mampu mengakomodasi prinsip-prinsip ideal dalam rangka mewujudkan transparansi dan akuntabilitas, sehingga mampu mendukung tercapainya Pemilu yang Fair dan berintegritas.

1. Sistem pemilu dan sistem pengelolaan dana kampanye

Pemilu diselenggarakan dalam sebuah kerangka sistem yang terdiri atas beberapa sub sistem yang saling berkaitan dan saling memengaruhi satu sama lain. Sistem pemilu adalah hubungan saling terkait antara instrumen-instrumen teknis pemilu yang terdiri dari: (1) besaran daerah pemilu, (2) metode pencalonan, (3) metode pemberian suara, dan (3) metode perhitungan suara. Hubunhan antara ke empat instrumen tknis tersebut, secara umum menghasilkan tiga sistem pemilu; yaitu (1) sistem pluralitas - mayoritas, (2) sistem semi proporsional, (3) sistem proporsional.

Pilihan atas sistem-sistem tersebut juga akan memengaruhi pola kompetisi antar kontestan serta model kampanye. Dalam sistem proporsional tertutup , kompetisi dalam pemilu lebih diwarnai oleh partai politik, yang akan mengendalikan proses penentuan nomor urut caleg, serta model dan bentuk kampanye. Model dan bentuk kampanye dalam sistem proporsional tertutup sangat ditentukan oleh partai politik karena kontestan utama dalam pemilu adalah partai politik. Sehingga institusi partai yang akan menentukan strategi dan bentuk kegiatan kampanye, teramsuk besaran biaya kampanye, target sumbangan dana biaya kampanye yang harus didapatkan dana bagaimana pembelanjaan dana Jurnal Komunikasi Bisnis dan Manajemen

Vol.5 No.2 Juli 2018 
kampanye akan dilakukan. Sedangkan dalam sistem proporsional terbuka, meskipun partai politik secara de jure merupakan peserta pemilu, namun corak kompetisinya lebih didominasi oleh peran pasangan caleg dalam menentukan strategi dan bentuk kegiatan kampanye.

Sistem penentuan pasangan caleg terpilih ditentukan berdasarkan atas perolehan suara caleg terbanyak dalam sitem proporsional terbuka, sehingga hal ini mendorong caleg untuk berlomba-lonba untuk menggalang dukungan pemilihan sebesar mungkin. Dalam tataran praksis, caleg berperan secara dominan dalam melakukan kegiatan kampanye, termasuk juga menggalang dana dan membelanjakan dana kampanye yang berhasil dikumpulkan. Partai politik bersifat lebih pasif atau terbatas pada mendesain strategi umum dan melakukan kegiatan kampanye secara umum. Perbedaan model kampanye dalam sistem proporsional terbuka dan sistem proporsional tertutup berimplikasi pada model pengelolaan dana kampanye.

Asmah mengatakan: IBC melakukan kajian terkait titik-titik rawan korupsi pilkada serentak tahun 2018. Hasilnya, menyebutkan bahwa sebanyak 10 provinsi dari 17 provinsi yang menyelenggarakan pilkada Gubaernur dan Wakil Gubernur berada dalam kategori sangat rawan. Hal ini disebabkan karena sistem pemilu dan sistem pengelolaan dana kampanye yang dilakukan.

Sistem pemilu di Indonesia adalah pemilihan mendasarkan pada UUD 1945 tentang sistem pemerintahan negara bahwa kekuasaan negara tertinggi di tangan MPR selanjutnay kedualatan rakyat dipegang oleh suatu badan yang bernama MPR, yang kemudian memiliki dua makna bahwa kekuasaan negara tertinggi berada di tangan rakyat, sedangkan makna kedua kedaulatan rakyat mengartikan bahwa rakyatlah yang memunyai wewenang tertingghi untuk menentukan segala wewewnang yang ada dalam suatu negara. Artinya, sitem negara adalah sistem perwakilan yang lazimnya dianut oleh negara-negara modern, maka dibentuklah suatu badan perwakilan rakyat disertai dengan diadakannya lembaga pemilihan umum, sebagai sarana bagi warga negara utnuk menunjuk wakil-wakilnya yang akan duduk di dalam Badan perwakilan Rakyat. 
Tahapan-tahapan yang dilewati daalm proses pemilihan umum meliputi: pendaftaran pemilih, pencalonan, kampanye, penyusujnan dan perhitunagn suara, pemantapan hasil pemilihan, peresmian atua pelantikan para calon terpilih. Orangorang yang akn dipilih terlebih dahulu mencalonkan diri/atau dicalonkan. Dalam kaitan dengan calon dan pencalonan ini maka timbul masalah-masalah siapa-siapa yang dapat mencalonkan diri atau mengajukan calon. Kemudian massalah selanjutnya adalah keadaan struktur masyarakat Indonesia, dan masalah lainnya yang timbul, seperti:

a. Jumlah penduduk yang tidak merata

b. Tingkat pendidikan penduduk Indonesia

c. Rasa persatuan berbangsa dan bernegara

Permasalah-permasalahan lain yang sensitif sifatnya seperti memeprtajam perbedaan suku bangsa, mempertajam perbedaan agama dan lain-lain. Kita harus mengakui kenuataan bahwa bangsa Indonesia ini baru dikatakan bersatu dalam bahasanya, sedangkan dalam aspek kehidupan lainnya belum dikatakanm bersatu secara umum. Khusus dalam hubungan denngan sitem pemilihan umum di Indonesia harus mengerti secara mendalam tentang pengertian demokrasi, hakikat pemilihan umumdan sistem pemilihan umum, karena pemilihan umum ini akan menmetukan nasib mereka, dan nasib negara kesatuan Republik Indonesia.

Kemudian Saberan juga menyebutkan bahwa munculnya permasalahan dalam penerapan peraturan KPU RI No 5 tahun 2017 tentang dana kampanye ini adalah karena sistem pemilu langsung yang dilaksanakan dalam sistem pemilu di Indonesia.

Sebenarnya sistem pemilu langsung yang digunakan saat ini tujuannya baik, yakni untuk menghasilkan pemimpin-pemimpin yang memiliki legitimasi dan kepercayaan penuh dari rakyat karena pada hakekatnya demokrasi adalah kekuasaan di tangan rakyat. Dibandingkan dengan sitem pemilihan sebelumnya yang melalui lembaga perwakilan sangat kental dengan nuansa politik uang dan politik transaksional.

2. Adanya proses Kampanye yang berbiaya tinggi 
Pilkada merupakan kegiatan dengan mengerahkan energi masyarakat dengan biaya yang sangat tinggi, terutama menyangkut biaya kampanye calon yang akan dipilih. Besarnya biaya yang dibutuhkan calon kepala daerah untuk pilkada, oleh sebagian pengamat politik dainggap sebagai penyebab meingkatnya perilaku korupsi di daerah pada pasca pelaksanaan pilkada. Biaya tinggi yang mereka keluarkan bahkan acapkali didanai dari utang, sehingga harus dapat dikembalikan ketiaka mereka sudah memperoleh jabatan. Namun, ketika jabatan ini menemui tembok berupa penghasilan terbatas, maka tentunya mereka bisa terjebak utnuk menyalahgunakan wewenang guna pengembalian modal yang telah dikeluarkan.

Yasin menyebutkan bahwa:" Tinggi biaya politik untuk bertarung dalam pemilihan kepala daerah (pilkada) menjadi salah satu pemicu untuk mengabaikan peraturan KPU tentang pelaporan dana kampanye dan beliau menyebutkan juga tinggi biaya politik seperti tingginya biaya proses kampanye juga menjadi salah satu pemicu maraknya korupsi di daerah, sebagaimana hasil kajian KPK menyebutkan bahwa untuk maju pilkada seorang kandidat kepala daerah membutuhkan biaya rata-rata Rp.20 M hingga Rp.30 M

Mendasarkan hasil kajian IBC tersebut kemudian Fadli menyatakan: " bahwa perlu dilakukan kerjasama Bawaslu, KPK dan Satgas antipolitik uang untuk meningkatkan pengawasan terhadap kandidat

Nainggolan mengakui bahawa tingginya biaya politik menjadi persoalan kompleks dan sulit untuk dihadapi, dan sistem pencegahan yang dibangun sulit untuk berjalan maksimal jika biaya politik masih tinggi

Dalam era politik modern, uang memainkan peranan utama dalam kontestasi politik Sebagaimana salah satu kutipan terkenal dari seorang pemimpin politik di California tahun 1960-an, Jesse unruh yang menyatakan" moneyas the mother' milk of politics".(Nassmacher, 2003:5). Kemudian dalam proses pengelolaan dana pemilu masih banyak yang belum menerapkan prinsip efisiensi dan efektivitas, sehingga banyak mendapat penolakan publik, seperti mengenai sistem pemilu hingga penambahan jumlah DPR, dan kenaikan batasan dana kampanye dan dana saksi dari negara. 
Untuk menghentikan politik biaya tinggi ini perlu dilakukan reformasi birokrasi. Soebhan (2005) mengemukakan prioritas utama yang perlu dilakukan dalam pelaksanaan reformasi birokrasi yaitu dengan mengenalkan konsep kewirausahaan di lingkungan birokrasi guna mendongrak kebangkitan ekonomi. Kemudian Gintings (2005) menambahkan bahwa untuk mengawali reformasi birokrasi melalui perbaikan pelayanan publik, sebagaimana yang dilakukan oleh berbagai negara yang melakukan perubahan sistem politik demokrasi. Peran birokrasi emmang sangat signifiakn dalam memperbaiki kondisi kehidupan bangsa dan negara yang sedang carut marut ini.

3. Konten kebijakan pemilu ( Peraturan KPU RI No.5 tahun 2017 )

Untuk mengefektifkamn implementasi kebijakan peraturan dana kampanye pemilihan kepala daerah, perlu dianalisis dari sisi konten kebijakan sehingga tidak menyisakan banyak kekurangan yang dapat menjadi celah bagi pelaksana peraturan untuk melakukan pengabaian atas peraturan tersebut. Jika aturan pelaksanaan di lapangan ternyata dinilai merugikan dan menyulitkan untuk dilaksanakan, maka kelompok sasaran dari peraturan tersebut akan melakukan tindakan yang berbeda, dan tetap mencari celah untuk mengakali aturan yang ada. Sehingga manfaat-manfat yang seharusnya dapat diciptakan dari aturan menjadi sia-sia. Fasilitasi dana kampanye oleh negara yang dilaksanakan oleh KPU menjadi tidak berarti ketika partai poplitik merasakan manfaat yang diberikan tidak sesuai dengan kebutuhan dan keinginan mereka

Fadli mengatakan: "temuan dana di luar rekening sangat penting dan menarik, dan sebenarnya menunjukkan ketidakjujuran paslon dalam membuat laporan dana kampanye. Semua dana kampanye, penerimaan dan pemasukan seharusnya wajib dilaporkan dan dicatat dalam rekwning. Ketika tidak dicatat berarti ada dugaan ketidak jujuran paslon dan ini bisa dikenakan sanksi yang tegas dan bisa pidana" tandas dia.

Syukriansyah mengatakan: "jika partai politik masih menerima dana kampanye dari sumber yang tidak jelas identitasnya dan tidak jujur pada saat pelaporan kepada publik dan Komisi Pemilihan Umum (KPU). Hal ini sangat memungkinkan 
karena aktivitas pendanaan kampanye masih penuh dengan transaksi keuangan yang dilakukan secara tunai atau dengan kata lain tidak melalui instrumen perbankan".

Kemudian Ibrahim menambahkan bahwa"dibutuhkan solusi yang tepat agar persoalan kejujuran pelaporan dana kampanye. Solusi yang tidak tepat tidak hanya akan tidak menjawab persoalan yang terjadi, tetapi juga akan melahirkan masalah baru.beliau menyebutkan beberapa solusi yang dapat dilakukan, seperti (1) perlu dilakukan perbaikan pengawasan dana kampanye dan audit inevstigasi atas laporan dana kkampanye, (2) perlu pembatasan sumbangan pihak ketiga untuk mengurangi ketergantungan kandidat pemilu terhadap big donors, yang nantinya akn berdampak panjang pada korupsi pra dan pasca pmilu. (3) ketergantungan kandidat pemilu pada big donors akan semakin menghilangkan pentingnya upaya meningkatkan partisipasu publik dalam pendanaan kampanye kandidat. Dana kamapnye yang sehat addalah dana kampanye yanag berasal dari banyak orang dalam jumlah sedikit (wajar) bukan sebaliknya.

Kebijakan dana kampanye yang menjadi bagian dari Undang Undang pemilihan kepala daerah lahir dari peraturan pengganti Undang-Undang (Perppu) yang proses pembuatannya insant tanpa proses pembuatan naskah akademik, serta proses uji publik dengan stakeholder pemilihan.

Proses Pelaporan dana kampanye menurut peraturan KPU RI NO. 5 tahun 2017 Bab III pasal 15 dimulai dari proses pencatatan dana kampanye menyebutkan bahwa dana kampanye wajib diperoleh, dikelola, dan dipertanggungjawabkan berdasarkan prinsip legal, akuntabel, dan trasnparan, dan pelaporannya menjadi tanggung jawab pasangan calon. Dana kampanye berbentuk uang yang bersumber dari psangan calon dan/atau partai politik atau gabungan partai politik, pasangan calaon perseorangan, dan sumbangan yang syah menurut hukum dari pihak lain wajib dicatat dan ditempatkan pada rekening khusus dana kampanye sebelum digunakan unuk kegiatan kampanye pemilihan.

Pasangan calon wajib mencatat semau penerimaan dan pengeluaran dalam pembukuan khusus dana kampanye terpisah dari pembukuan keuangan pribadi pasangan calon. Pasnagn calon wajib menysun dan menyampaikan laporan dana kampanye kepada KPU. Dalam penysuunan laporann dapat dibantu staf khusus 
yang memunyai latar belakang akuntansi. Laporan dana kampanye yang dilaporkan terdiri dari: LADK,LPSDK, dan LPPDK.

4. Implementasi Konteks Kebijakan pemilu ( Peraturan KPU RI No.5 tahun 2017 )

Implementasi konteks kebijakan memperlihatkan besarnya kekuatan aktor dalam memengaruhi efektivitas impementasi kebijakan, pertarungan dan konflik para elit partai politik dalam memperoleh keuntungan dalam penerapan aturan dana kampanye. Implementasi pengaturan dana kampanye pada pilkada tahun 2018 bertujuan agar terwujudnya transparansi dan akuntabilitas publik, melalui adanya proses pencatatan, pengelolaan, dan pelaporan dana kampanye, dan merupakan suatu hal yang penting dalam meningkatkan kepercayaan publik terhadap proses penyelenggaraan pemilu yang langsung, umum, bebas, rahasia, jujur, dan adil. Peraturan KPU RI No. 5 tahun 2017 menegaskan bahwa audit atas LPPDK beserta laporan terkait yang dilakukan oleh KAP merupakan audit yang dilaksanakan dengan menggunakan bentuk perikatan prosedur yang disepakati.

Kemudian saberan Menambahkan: "untuk menjawab tidak jujurnya pelaporan dana kampanye, DPR seharusnya merancang pengaturan yang dapat mengadakan pengawasan penerimaan dan belanja dana kampanye sejak awal masa kampanye, serta mengubah ketentuan audit kepatuhan menjadi audit investigatif. Selain itu pembenahan juga perlu dilakukan dalampengaturan dana partai politik, sehingga partai politik tidak menjadi alternatif untuk menghindari batasan sumbangan dan trasnparansi dana kampanye.

Kemudian Fadli menambahkan: bahwa Bawaslu perlu juga menggandeng masyarakat untuk meningkatkan pemantauan dan pelaporan terkait politik uang dan penggunaan fasilitas serta anggaran daerah untuk pemenangan.

Untuk mencegah penyelewengan dana kampanye, mencegah adanya politik uang dalam pelaksanaan kampanye, dan untuk meningkatkan transparansi, perlu tersediannya SDM yang cukup dalam pelaksanaan pemilu, dengan mengutamakantingkat pendidikan kader yang cukup serta tingkat kompetensi SDM yang ada pada partai politik, serta teredianya SDM yang memiliki kompetensi akuntansi, sehingga dapat mengimplementasi peraturan KPU tersebut dalam hal pelaporan dana kampanye.

Jurnal Komunikasi Bisnis dan Manajemen

Vol.5 No.2 Juli 2018 
Sebagaimana yang diungkapkan oleh Nainggolan bahwa:"partai-partai yang berkomunikasi dengan KPK pun mengeluh bahwa untuk menjalankan roda organisasi partai dibutuhkan dana yang cukup tinggi, dan memiliki kompetensi akuntansi bagi kader-kader pada partai serta tingkat pendidikan kader yang cukup tinggi.

Berdasarkan keluhan-keluhan partai tersebut artinya, untuk melaksanakan peraturan KPU RI, N0. 5 tahun 2017 sesuai dengan yang diamanahkan memerlukan pengumpulan dana yang cukup, kader yang berpendidikan cukup tinggi dan memiliki kompetensi di bidang akuntansi untuk membuat laporan dana kampanye sebagaina diamanatkan dalam peraturan tersebut.

\section{KESIMPULAN}

Berdasarkan analisis deskriptif dari berbagai pendapat dari para informan dapat ditarik kesimpulan tentang determinan kesesuaian penerapan peraturan Komisu Pemilu RI NO. 5 tahun 2017 tentang dana kampanye peserta pemilihan Gubernur dan Wakil Gubernur, Bupati dan Wakil Bupati, dan/atau Walikota dan wakil walikota dapat dibutiri adalah:

1. Sistem pemilu dan pengelolaan dana kampanye - sistem pemilu langsung yang memicu paslon untuk tidak mengimplementasikan peraturan tersebut, serta menjadi pemicu untuk melaksanakan tindakan korupsi pasca pemilihan. Serta kesulitan dalam pengelolaan dan penyusunan laporan dana kampanye

2. Proses kampanye yang berbiaya tinggi, sehingga mendorong paslon untuk berusaha mengumpulkan dana kampanye sebanyak-banyaknya dan berusaha menutupi sumber penerimaan dan pengeluaran dana kampanye, dan dapat menjadi alasan bagi paslon tidak melaksanakan peraturan KPU RI no. 5 tahun 2017

3. Konten kebijakan yang belum begitu dipahami oleh paslon sehingga sulit dan bahkan tidak dapat untuk mengimplementasikannya

4. Implementasi konten kebijakan yang tidak bisa dilakukan karena, tidak tersedianya SDM yang cukup dan kompetensi SDM juga kurang, serta berkaitan dengan pendidikan Kader yang masih kurang. 


\section{SARAN}

1. Perlu pengkajian ulang tentang sistem pemilu yang dilaksanakn dan pengelolaan dan kampanye

2. Solusi untuk mengatasi biaya politik yang tinggi dari sistem yang ada sekarang:

a. Penunjukkan secara politis

b. Pemilihan yang tyidak melibatkan partai politik, contohnya pemilihan kepala daerah yang hanya diikuti oleh calon perseorangan yang tidak berafiliasi dengan partai politik (calon independen)

c. Pemilihan berdasarkan merit system, yaitu pemilihan seseorang yang akan menduduki jabatan tertentu melalui proses seleksi terbuka yang berbasias kualifikasi, kompetensi dan integritas sehingga proses seleksi lebiuh bermutu, trasnparan dan akuntabel.

d. Perlu pembatasan belanja kampanye pilkada

3. Saran bagi peneliti selanjutnya, bahwa beberapa determinan yang kami tangkap dari key person dapat dilanjutkan untuk penelitian selanjutnya dengan pendekatan yang berbeda (misalnya dengan pendekatan kuantitatif).

\section{DAFTAR PUSTAKA}

Dirsa Andika, Nurharmi, Hendrizal.2013. Faktor-Faktor yang memengaruhi Partisipasi Politik masyarakat dalam pilkada kota padang. Downloads file:///C:/users/Windows\%2010/5097-17905-1-PB dowload tanggal 10 pebruari 2018.

Gintings, Sutradara.2005. Saatnya Birokrasi Di reformasi. Jakartaa: Kompas onbline,10/12/2005

Lujambio, Alonso (2004)"Enforcemnent: The experienbce in Mexico" In Hodess, Robin (ed) Global Corruption Report 2004: Transparency International. Pluto Press. London

Ohman, Magnus \& Zainulbhai, Hani (2009) regulating Political Finance, The Global experience, IFES, Washington.

Peraturan Komisi pemilu Nomor 05 tahun 2017 tentang Dana Kampanye

Soebhan, Syafuan Rozi (2005) dalam saatnya Birokrasi di reformasi. Jakart: Kompas online 10/12/2005

Sugiwa Iwan, Muthia Putri Arifah; Hasan Kamal Farobi, 2015. Analisa tingkat kepatuhan pelaporan dana kampanye partai politik peserta pemilu 
berdasarkan hasil audit laporan dana kampanye di Provinsi Bali pada Pemilu Legislatif 2014. Jurnal Ekonomi dan Bisnis Vol.14.No.1. 2015:35-40

Taufiq Aly.2015. Fenomena Politik uang dan keterlibatan pemuda. Studi kasus pada Pemilu legislatif 21014 di Bojonegoro. Blog Kompasiana.download 10 pebruari 2018

Undang-Undang Nomor 2 tahun 2011 tentang Partai Politik

Undang-Undang Nomor 8 tahun 2012 tentang partai politik

Walecki, Martin (2004) Assessment of Enforcement of Political Finance laws by KNAB Division of control of Financing of Political parties" Report prepared for the corruption prevention and combatting bureau, Riga. 